\title{
A Theory of a State? How Civil Law Ended Legal Pluralism in Modern Egypt
}

\author{
Samy A. Ayoub \\ Assistant Professor of Law and Middle Eastern Studies, University of Texas at Austin
}

\begin{abstract}
'Abd al-Razzāq al-Sanhūrī (d. 1971), the father of the Egyptian legal code, theorized a relationship between din (religion) and dawla (state) that was key to his project. In this relationship, al-Sanhūrī posited a delineation between the spheres of din and dawla that allowed him to map these categories onto the existing distinction between matters of 'ibādāt (acts of worship) and mu'āmalāt (transactions) in Islamic law ( figh). I propose that Islamic jurisprudential distinctions between 'ibādāt and mu'āmalātfor al-Sanhūri-was the ideal medium to maintain and police the borderlines between religion and state in the postcolonial Egyptian state. Al-Sanhūrī's objective was to keep the domain of din outside of state sanction and to facilitate a transition whereby the state's legal institutions assumed exclusive lawmaking powers based on its own independent legal reasoning in Islamic law (ijtihād). I argue that al-Sanhūrī was a committed comparatist, not a reformer of Islamic law. Al-Sanhūrī's legal project should be viewed as a faithful commitment to French comparative law as a method of legal inquiry and a reflection of his nationalist agenda of creating a unified legal order that cannot exist without relying upon indigenous forms of law and culture. Al-Sanhūrī saw Khedival legal pluralism as an obstacle for national sovereignty. As a result of the institutional and legal readjustments from the 1920s through 1950s in Egypt, al-Sanhūrī did not see a future for Islamic law in the emerging legal state apparatus outside of civil law strictures and insisted that Islamic courts and religious tribunals for Jews and Christians must be subsumed under nationalized secular state courts.
\end{abstract}

Keywords: Islamic law; Egypt; state; religion; courts; civil law

\section{Locating Islamic Law in Egypt}

A particular line of arguments has long dominated discussions about 'Abd al-Razzāq al-Sanhūrī (d. 1971), civil code, and Islamic law in modern Egypt. A common problem with these existing treatments of modern Egyptian legal history is the assumption that Islamic law became a formative source of legislation only upon the ratification of the second article in the 1971 Egyptian constitution, which states that "principles of Islamic law are the prime source of legislation." "This so-called Sharīa Article in the 1971 constitution appears to be viewed, especially in intra-Egyptian polemics, as a watershed moment in which Islamic law is (re)inscribed in the Egyptian legal and constitutional order. However, this narrative ignores the fact that most Egyptian constitutions-including the 1923 constitution, in article

\footnotetext{
${ }^{1}$ The prominent Egyptian judge Tāriq al-Bishrī (d. 2021) made this argument in an article published in Al-Ahram, Egypt's major newspaper: Tāriq al-Bishrī, "Ḥawl al-Māda al-Thāniyya min al-Dustūr" [On the Second Article of the Constitution], Al-Ahram, March, 10, 2007. The article was later included in his book al-Dawla wa al-Kanisa. Tāriq al-Bishrī, al-Dawla wa al-Kanīsa [Church and state] (Cairo: Dār al-Shurūq, 2011), 65-76. Unless otherwise noted, all translations from the Arabic-language sources are mine.
} tivecommons.org/licenses/by/4.0/), which permits unrestricted re-use, distribution, and reproduction in any medium, provided the original work is properly cited. 
149-have stated that "Islam is the religion of the state and Arabic is its official language." Until 1955, Islamic and Jewish courts and Christian tribunals-although with limited jurisdiction over personal status matters-were standing institutions with a sophisticated set of regulations, procedures, and dedicated staff and personnel. ${ }^{3}$

My interest here is to show how the sovereign power of a national state was theorized and justified by a key Egyptian intellectual and to examine the concepts that underpin the normative secular power of the Egyptian state. In doing so, I explore the question beyond the welltrodden concepts of importation, introduction, and translation of the term secularism into Arabic in late nineteenth-century Egypt. ${ }^{4}$ I propose that Islamic normative categories-in the case of al-Sanhūrī-were central to the articulation of a secular political order in Egypt. ${ }^{5}$ He relied upon the Islamic legal distinction between 'ibādāt and mu'ämalāt within the figh tradition as the medium to facilitate these borderlines between religion and state or din and dawla. ${ }^{6}$ Thus, I challenge some treatments which confine the relevance of Islamic law in Egypt to president Anwar al-Sadat's (d. 1981) constitutional changes of 1971. ${ }^{7}$ I submit that the objective of al-Sanhūrì's scholarly endeavor, at this point, was institutional secularization: ${ }^{8}$ to formulate a political order, a theory of a state, in which Islamic law could play a key role in theorizing

\footnotetext{
${ }^{2}$ Dustūr al-Mamlaka al-Mișriyya [The Constitution of the Egyptian kingdom] (Cairo: Matbaca Hindiyya, 1923), 32.

${ }^{3}$ Aware of the valid critical points raised by Lena Salaymeh in her essay on secular translation of Islamic tradition, I use the term religion as a translation of dinn, as deployed by al-Sanhūrī, because of his construction of the term as a private normativity. In her essay, Salaymeh uses translation as a "metonym for secular transformations." She proposes that "secularism converts legal traditions into religious law." Salaymeh argues that the Arabic term sin) is not "religion," despite its habitual mistranslation in this way. She explains that "religion was and continues to be constituted in dialogical relationship to secularism." She elaborates that secular ideology "converts Islamic tradition دين (din) into a religion with sharia (religious laws) and ethics." Furthermore, Salaymeh's concept of "secularization triangle" is very helpful for explaining her view of how secular state law constructs religions in three angles, namely: religiosity, religious law, and religious group. This secularization triangle, for Salaymeh, "illuminates that the secular construction of religious law corresponds to sharia. Thus, sharia is defined not by the Islamic tradition, but by secularism." Lena Salaymeh, "Decolonial Translation: Destabilizing Coloniality in Secular Translations of Islamic Law," Journal of Islamic Ethics 5, nos. 1-2 (2021): 250-77, at 252, 263, 264.

${ }^{4}$ Talad Asad has suggested that the most common Arabic word used today for the adjectives secular and lay (and secularist and layman) is 'almāniyya. Asad explains that this word was coined in the latter part of the nineteenth century. Talal Asad, Formations of the Secular: Christianity, Islam, Modernity (Stanford: Stanford University Press, 2003), 206.

${ }^{5}$ Probably inspired by al-Sanhūrī, Mohammad Fadel recently made a similar argument. He maintained "that Islamic law (figh), far from reflecting an obstacle to secularization-at least in the institutional differentiation sense-was historically a catalyst for it." Fadel relied upon Jose Casanova's three forms of secularization that are characteristic of modernity: institutional differentiation, privatization of religious belief, and the decline of religious belief. To Casanova, while all three of these modes of secularization are present in modernity, only the first-the institutional differentiation of various social spheres from religious institutions, such as the market, the state, and the economy-is a universal prerequisite for modernity. Mohammad Fadel, "Islamic Law, Secularization, and Modernity: Two Islamic Conceptions of the Human," Contending Modernities: Exploring How Religious and Secular Forces Interact in the Modern World (blog), July 30, 2020, https://contendingmodernities.nd.edu/theorizing-modernities/islamiclaw-secularization-modernity/.

${ }^{6}$ Hussein Agrama accepts that there were "certainly discussions and instances of the separation of temporal and spiritual power during, for example, medieval Christian and Islamic times, they nevertheless arose under very different presuppositions, and legal, political, and social conditions, and thus elicited and mobilized very different desires and anxieties." Hussein Agrama, "Secularism, Sovereignty, Indeterminacy: Is Egypt a Secular or a Religious State?" Comparative Studies in Society and History 52, no. 3 (2010): 495-523, at 501.

${ }^{7}$ For detailed discussion on the role of Islamic law in the Egyptian constitution, see Mohammad Fadel, "Judicial Institutions, the Legitimacy of Islamic State Law and Democratic Transition in Egypt: Can a Shift toward a Common Law Model of Adjudication Improve the Prospects of a Successful Democratic Transition?" International Journal of Constitutional Law 11, no. 3 (2013): 646-65; Baber Johansen, "The Relationship Between the Constitution, the Sharîa and the Fiqh: The Jurisprudence of Egypt's Supreme Constitutional Court," Zeitschrift für Ausländisches Öffentliches Recht und Völerrecht, no. 64 (2004): 881-96, at 881-82. Clark Lombardi provides the most sustained discussion on the case law emanating from Article 2 of the Egyptian constitution on the shari' $a$. Clark Lombardi, State Law as Islamic Law in Modern Egypt: The Incorporation of the Shari'a into Egyptian Constitutional Law (Leiden: Brill, 2006).

${ }^{8}$ Fadel, "Islamic Law, Secularization, and Modernity."
} 
its institutions and forging its legal order. ${ }^{9}$ Furthermore, I maintain that al-Sanhūrī's legal project should be viewed as a faithful commitment to French comparative law as a method of legal inquiry and a reflection of his nationalist agenda of creating a unified national legal order that cannot exist without relying upon indigenous forms of law and culture. ${ }^{10}$

What seems to be overlooked in some treatments of modern Egyptian legal history is how contentious concepts in al-Sanhūrīs thought such as sovereignty have been taken for granted, when in fact, there are records of lengthy discussions on its Arabic rendering and translation into siyāda in the 1920s. Similarly, the debates on the actual interworking of the institutional demarcations between secular political power and religious bodies in post-Ottoman Egypt indicate that these boundaries were unsettled and indeterminate. ${ }^{11}$ The ratification of the 1923 constitution by Egyptian nationalists after the declaration of independence in 1922 was viewed by some scholars as, "a legal revolution which reversed the traditional relationship between the sovereign and the Shari'ah. Instead of his being under it, it was placed under him, along with the general affairs of the state."12 Salaymeh has made a similar observation and maintains that the Islamic constitutionalism that emerged in the late nineteenth century transformed the way Islamic law is inscribed in these constitutional orders. She states, "While Islamic law was initially understood as a limit on governance, it eventually became identified in various constitutions as a source of law."13

The adoption of civil law in Egypt, in al-Sanhūrī's reading, was driven by compelling political calculations to limit the impact of capitulations during the reign of Khedive Ismā̄ìl (d. 1895) and his prime minister, Nūbār Pasha (d. 1899). ${ }^{14}$ After concerted political efforts, the Mixed Courts were created, which entailed wholesale borrowing of civil, procedural, commercial, maritime, and criminal law from the French code. ${ }^{15}$ Although

\footnotetext{
${ }^{9}$ Enid Hill points to the nationalism and nationalist causes embraced by al-Sanhūrī. Enid Hill, "Al-Sanhuri and Islamic Law: The Place and Significance of Islamic Law in the Life and Work of 'Abd al-Razzaq al-Sanhuri, Egyptian Jurist and Scholar, 1895-1971 [Part 2]," Arab Law Quarterly 3, no. 2 (1988): 182-218, at 185. Hill's article published in two parts across two issues of Arab Law Quarterly. Part I appeared in the prior issue as "Al-Sanhuri and Islamic Law: The Place and Significance of Islamic Law in the Life and Work of 'Abd al-Razzaq al-Sanhuri, Egyptian Jurist and Scholar, 1895-1971 [Part 1]," Arab Law Quarterly 3, no. 1 (1988): 33-64. Subsequent citations indicate either Part 1 or Part 2.

${ }^{10}$ Leonard Wood argues that al-Sanhūrī's encounter with comparative law was not simply about comparison of laws and legal history. He explains that "French comparative law at this time comprised pre-packed premises, methods, theoretical preoccupations, and practical objectives with regard to legal history, contemporary legal study, and the future of legal reform." Leonard Wood, "Al-Sanhuri's Theory of Rights in Islamic Jurisprudence: The Final Act of Franco-Egyptian Comparative Law," Maghrib Review 45, no. 4 (2020): 865-94, at 872-73. Guy Bechor argued, the new civil code proposed by al-Sanhūrī underpins "the foundation of a firm and comprehensive social perception relating to the unique environment and absorptive capacity of Egyptian society, and with the goal of engendering a change in the values embodied in the social structure of the Egyptian collective." Guy Bechor, The Sanhuri Code, and the Emergence of Modern Arab Civil Law (1932 to 1949), (Leiden: Brill, 2007), 2-3.

${ }^{11}$ Al-Dustūr: Ta'līqāt 'alā mawādih bi al-'amāl al-tahdịiriyya wa al-munāqashāt al-barlamānìyya [The Constitution: Commentaries on its articles, meeting minutes of its drafters, and parliamentary discussions], 4 vols. (Cairo: Mațbacat Mișr, 1940), 1:2-7. Members of the constitutional committee in 1922 suggested the use of the Arabic word wilāya instead of siyāda. Mohammad Fadel proposed that the adoption of the term siyāda instead of wilāya "is significant because siyāda implies a top-down relationship between commander and commanded, a connotation that comes out in 'Abd al-'Aziz Fahmy's comment, a member of the constitutional committee, whereas wilāya creates a reciprocal moral relationship between the office-holder and the ruled that is itself regulated by law." Mohammad Fadel, professor, Faculty of Law, University of Toronto, in discussion with the author, August 18, 2020.

${ }^{12}$ Nadav Safran, "The Abolition of the Sharī'a Courts in Egypt II: An Assessment," Muslim World 48, no. 2 (1958): $125-35$, at 132.

${ }^{13}$ Lena Salaymeh, "Islamic Law," in International Encyclopedia of the Social and Behavioral Sciences, ed. James D. Wright, 2nd ed. (Amsterdam: Elsevier, 2015): 746-53, at 751.

14 'Abd al-Razzāq Aḥmad al-Sanhūrī, "Min Majallat al-Aḥkām al-'Adliyya ilā al-Qānūn al-Madanī al-'Irāqī wa Harakat al-Taqnīn al-Madanī fī al-'Ușūr al-Hadītha" [From the Mecelle to the Iraqi civil law: The codification movement in the modern period], in "Maqalāt wa Abhāth al-Duktūr 'Abd al-Razzāq al-Sanhūrī" [Research articles of Dr. 'Abd al-Razzāq al-Sanhūrī], special issue, Majallat al-Qānūn wa al-Iqtișād 1, no. 1 (1992): 269-325, at 280.

${ }^{15}$ Al-Sanhūrī, "Min Majallat al-Ahkām al-'Adliyya," 280. Al-Sanhūrī writes that these codes, taken primarily from French civil law, were promulgated by a foreign lawyer based in Alexandria, named Manoury, who was later
} 
al-Sanhūrī saw many faults and issues with these early codification attempts in Egypt, he embraced these codes as a welcome paradigmatic shift. Al-Sanhūrī and the nationalist legal elites of the early twentieth century, driven by a strong commitment to end the capitulations, rejected Khedival legal pluralism, and insisted on a unified national court system and single code for all Egyptians, regardless of their religious tradition or national origin. Al-Sanhūrī saw legal pluralism as an obstacle to national sovereigntyspecifically a type of sovereignty exercised in Italy and France. ${ }^{16}$ For al-Sanhūrī, lawmaking is a concomitant symbol of sovereignty. I maintain that the emergence of civil law in Mixed and National courts, in 1875 and 1883 respectively, should be understood as a transplantation of a legal system in late nineteenth-century Egypt. The adoption of civil law and the subsequent projects to codify and unify all legal and court systems were an indication of the increasingly hegemonic status of a certain legal logic of reform among political and legal elite.

\section{Al-Sanhuirì: Islam Is "Din wa Dawla"}

'Abd al-Razzāq al-Sanhūrîi ${ }^{-17}$-the father of the Egyptian legal code-theorized a relationship between religion and state in an article titled "Al-dīn wa dawla fī Islām"18 published in Majallat al-Muhāmāh al-Shariyya ${ }^{19}$ in October 1929, two years after he finished his doctoral studies at the University of Lyon. ${ }^{20}$ This article is the only Arabic summary by al-Sanhūri himself of his second dissertation, on the caliphate. ${ }^{21}$ It was published in a time of deep

appointed in the committee that created the Mixed Courts. Similarly, Moriondo, an Italian lawyer appointed as a judge in the Mixed Courts, was the key person who supervised the efforts to formulate a code for the National Courts in 1883. This latter relied heavily on the codes of the Mixed Courts. Al-Sanhūrī also revealed that Qadrī Pasha (d. 1888), the minister of justice, participated in the committee that put forward the code of National Courts of 1883 .

${ }^{16}$ 'Abd al-Razzāq Ahmad al-Sanhūrī, "Wujūb tanqīh al-qānūn al-madanī al-miṣrī" [The necessity of revising Egyptian civil law], Majallat al-Qānūn wa al-Iqtiṣād 6, no. 1 (1936): 3-144, at 63.

${ }^{17}$ There is a significant body of scholarship on al-Sanhūrī's legal and political career. On al-Sanhūrī's writings on the theme of din wa dawla, Muhammad 'Imāra published a booklet with al-Azhar magazine in 2011 summarizing some of his views. Muhammad 'Imāra, ed. Al-Dīn wa al-Dawla fì al-Islām [Religion and state in Islam] (Cairo: Dār al-Jumhūriyya, 2011). Many scholars have attempted to assess al-Sanhūrîs views on the state, law, and society. For example, Hill, "Al-Sanhuri and Islamic Law [Part 1]"; Amr Shalakany, "Between Identity and Redistribution: Sanhuri, Genealogy and the Will to Islamise," Islamic Law and Society 8, no. 2 (2001): 201-44.

${ }^{18}$ One of the contentious issues in contemporary Arab thought is the relationship between al-din and al-dawla. The continuous relevance of this issue is animated by both the authoritarian regimes in the region and Islamist movements. For detailed studies on this issue see, for instance, Raḍān al-Sayyid, Al-Ummah wa al-Jamā'a wa al-Sulța [The religious community, the political community, and the state] (Beirut: Dār Iqrac', 1985); Raḍān al-Sayyid, Al-Jamāa $\bar{a}^{\prime}$ wa al-Mujtama’ wa al-Dawla [The political community, society, and the state] (Beirut: Dār al-Kitāb al-'Arabī, 1997); Burhān Ghalyūn, Naqd al-Siyāsa: al-Dīn wa al-Dawla [Critique of politics: religion and the state] (Casablanca: al-Markaz al-Thaqāfī al-'Arabī, 2007); Taha Abdurrahman, Rawh al-Dīn: min Dīq al-'Allmāniyya 'ilā Si'at al-'Itimāniyya [The spirit of tradition: From the confinement of secularism to the flexibility of trusteeship] (Casablanca: al-Markaz al-Thaqāfi al-`Arabī, 2012). For a study of the earliest usage of the label din wa dawla, see Sabine Schmidtke, "Abū al-Ḥusayn al-Bașrī and his Transmission of Biblical Materials from Kitāb al-Dīn wa al-Dawla by Ibn Rabbān al-Ṭabarī: The Evidence from Fakhr al-Dīn al-Rāzī's Mafātī al-ghayb," Islam and ChristianMuslim Relations 20, no. 2 (2009): 105-18. See also, M. Bouyges and Alphonse Mingana, Le Kitāb Al-dīn Wa-al-dawla [The book of religion and the state] (Beirut: Imprimerie Catholoque Beyrouth, 1924), a critique by Bouyges of Mingana's attribution of Kitāb al-Dīn wa al-Dawla to Ibn Rabbān al-Ṭabarī.

19 'Abd al-Razzāq al-Sanhūrī, "Al-dīn wa al-dawla fī al-Islām" [Religion and state in Islam], in Majallat al-Muhāmāh al-Shariyya, year 1, no. 1 (1929): 8-14.

${ }^{20}$ Wood argues that al-Sanhūrī, while in Lyon, "found inspiration to study Islamic law within the context of comparative law and developed an ambition to revive and reform both Egypt's national law and Islamic law." Wood, "Al-Sanhuri's Theory of Rights in Islamic Jurisprudence," 869.

${ }^{21}$ 'Abd al-Razzāq al-Sanhūrī, Fiqh al-Khilāfa [The jurisprudence of the Caliphate], trans. Tawfīq al-Shāwī and Nādya al-Sanhūrī (Cairo: Dār al-Risāla, 2000). This is a partial translation of the legal section of al-Sanhūrī's dissertation. The translators (al-Sanhūrī's daughter and son-in-law) were criticized for their heavy editorial intervention in 
uncertainty among Muslims after the abolishment of the Ottoman caliphate in 1924. In it, al-Sanhūrî́ ${ }^{-22}$ proposed a relationship between the Islamic legal tradition, Franco-Egyptian law, ${ }^{23}$ and the emerging Egyptian state institutions, wherein the domain of din was intentionally kept outside of state sanction. ${ }^{24}$ Al-Sanhūrī argued that the postcolonial Egyptian state inherited aspects of the Ottoman caliphal authority that allowed it to assume the power to determine religious legal norms for Egyptians. Thus, the recalibration of the sovereign authority of the emerging Egyptian nation-state in the mid-twentieth century-as theorized by al-Sanhūrī-was presented as an extension of the siyāsa sharciyya (discretionary power of the political ruler), or at least can be constructively harmonized with Sunni political thought.

Al-Sanhūrī recognized the historical and political significance of the caliphate in this article and thus argued for a Muslim political project in which the core values of the caliphal order could underpin emerging Muslim states. ${ }^{25}$ Al-Sanhūrī contended, in their role acting on behalf of the Muslim community, that the Muslim heads of state should apply Islamic law as independent jurists (mujtahids) and avoid embracing a particular Islamic legal school (madhhab). ${ }^{26}$

Al-Sanhūrī organized his article around three key issues: (1) "Islam is a religion and a state," (2) "public authorities in the Islamic state," and (3) "history of these authorities in Egypt." Under "al-Islām dīn wa dawla," 28 al-Sanhūrī states, Islam is a distinct tradition because it is a religion (din) and a state (dawla). ${ }^{29}$ He contends that the Prophet

working from the original French text. A complete and revised translation into Arabic was published recently by Nohoudh Center in Kuwait. 'Abd al-Razzāq al-Sanhūrī, Al-Khilāfa wa Tațawwurihā 'ilā 'Ușbat Umam Sharqiyya [The Caliphate and its transformation into a political Eastern bloc], trans. Kamāl Jād Allāh, Sāmī Mandūr, and Ahmad Lāshīn (Kuwait: Nohoudh Center for Studies and Publications, 2019).

${ }^{22}$ Al-Sanhūrī was active politically as a member of the Saadist Party (a faction of the Wafd Party), a minister, and a president of the Majlis al-dawla (State Council). This made him a target of the Wafd Party and its ministers. Nathan J. Brown, Rule of Law in the Arab World: Courts in Egypt and the Gulf (Cambridge: Cambridge University Press, 1997), 73.

${ }^{23}$ This term was coined by Wood to refer the emergence of a hybrid tradition in the early twentieth-century Egypt. Leonard Wood, Islamic Legal Revival: Reception of European Law and Transformations in Islamic Legal Thought in Egypt, 1875-1952 (Oxford: Oxford University Press, 2016), 209.

${ }^{24}$ Bechor argues that these categories deployed by al-Sanhūrī "attempted to dismantle the unity and totality of Divine Islamic ruling (the shari ${ }^{-} a$ )." Bechor, The Sanhuri Code, 48. It is important to note that Asad contends that in the context of Egypt "the state is not a cause but an articulation of secularization." Asad, Formations of the Secular, 209.

${ }^{25}$ Amr Shalakany points out that al-Sanhūrī published his second doctoral dissertation, Le Califat, on the caliphate in 1926 ('Abd al-Razzāq, Le Califat [Paris: Librairie Orientaliste Paul Geuthner, 1926]). Shalakany views al-Sanhūrī's theorization of a modern form of caliphate as an indication of the "anxieties" of postcolonial identity. He states, "On a deeper and more personal level, Le Califat appears to be an existential exercise in which Sanhuri confronts the anxieties of post-colonial identity and strives to resolve his own conflicting feelings for the West." Amr Shalakany, "Between Identity and Redistribution: Sanhuri, Genealogy and the Will to Islamise," Islamic Law and Society 8, no. 2 (2001): 201-44, at 211.

${ }^{26}$ It is important to note that al-Sanhūrī's reconfigurations of the Islamic legal tradition within the modern Egyptian state was facilitated by his commitment to a potential emancipatory politics and democratic state that never materialized, even after his support for the 1952 coup. Bechor, The Sanhuri Code, 37. This position is tightly maintained in the contemporary jurisprudence of the Egyptian Supreme Constitutional Court. Clark Lomdardi explains that the term ijtihād recurs consistently in the Court's Article 2 opinions. He maintains that the Supreme Constitutional Court employs the term to describe "the process that a wali al-amr should use to come up with regulations for behavior that is not governed by clear scriptural rulings." Clark Lombardi, State Law as Islamic Law in Modern Egypt: The Incorporation of the Shari` a into Egyptian Constitutional Law (Leiden: Brill, 2006$), 181$.

${ }^{27}$ Al-Sanhūrī, "Al-dīn wa al-dawla fĩ al-Islām," 8.

${ }^{28}$ Al-Sanhūrī, 8. The label din wa dawla appears in book titles about revivalist movements in the first half of the twentieth century. For example, Muhammad Fu'ād Shukrī, Al-Sanūsiyya Dīn wa Dawla [Al-Sanūsiyya: Religion and state] (Cairo: Dār al-Fikr al-'Arabī, 1948). Also, there are important works by contemporary Arab intellectuals on the relationship between religion and state. Burhān Ghalyūn, Naqd al-Siyāsa: al-Dīn wa al-Dawla [Critique of politics: religion and the state] (Casablanca: al-Markz al-Thaqāfī al-`Arabī, 2007); Raḍān al-Sayyid, Al-Jamā' $a$ wa al-Mujtama' wa al-Dawla [The Muslim community, society, and the state] (Beirut: Dār al-Kitāb al-'Arabī, 2007).

${ }^{29}$ Al-Sanhūrī, "Al-dīn wa al-dawla fì al-Islām," 8. 
Muhammad was sent not only to establish a religion ( $\operatorname{din}$ ) but also to lay the foundation of a state (dawla) that manages the daily affairs of individuals. ${ }^{30}$ In this understanding, al-Sanhūrī maintains that Muhammad is considered the founder of the Islamic government (huküma islāmiyya) and a Prophet (nabi) for Muslims. ${ }^{31}$

Al-Sanhūri posits that, as the founder of a state, the Prophet had authority (wilāya) over all of those who submitted themselves to the state-whether they were Muslims or not. However, in his capacity as a messenger, al-Sanhūrī elaborated, the Prophet did not demand recognition for his prophethood (nubuwwūa) from non-Muslims who adhered to their religions, despite his message being universal to all humans. ${ }^{32}$ To al-Sanhūrī, therefore, it is imperative to differentiate between Islam as a religion and as a state, although Islam combines both. The benefit of this differentiation-according to al-Sanhūrī-is that matters of din are studied with a different method (he uses the Arabic word rūh, meaning spirit or soul) than that applied to matters of the state. ${ }^{33}$ In other words, the capacity of the Prophet Muhammad and his role as political leader and a messenger allows al-Sanhūrī to theorize a distinct relationship between Muslim religious commitments and state affairs in Egypt. To al-Sanhūrī, dīn is concerned with the relationship between the individual and their Creator. Din does not change and it should not change. God is eternal without a beginning or an end. God is not susceptible to change. The relationship between God and his creation is permanent. ${ }^{34}$ By contrast, al-Sanhūrī viewed matters of the state to be contingent upon public interest (mașlaha) and rational management (tadbir). ${ }^{35}$

Al-Sanhūrī emphasizes that the domain of the state has two distinct particularities. The first feature is that state affairs are subject to rational judgment (hukm 'uqūlanā). God endowed humans with rational faculties to distinguish between good and evil. These rules that relate to the daily affairs of individuals are based on rational judgment and anchored in mașlaha, where the rational faculty (al-'aql) guides them to this mașlaha. ${ }^{36}$ To al-Sanhūrī, we establish knowledge based on 'aql, because knowledge ('ilm)-whether it is based on social or natural sciences-cannot be attained without rational capacity. Therefore, reason ( $\left.a l^{-} a q l\right)$ is the foundation (al-asās) of knowledge for state affairs. Al-Sanhūrī elaborates that the Prophet used to consult with others on the management (tadbir) of the daily affairs of the community because it is a matter of rational judgment. ${ }^{37}$ Like us, al-Sanhūrī confirms, the Prophet was a human being and in need of consultation in matters determined by reason for which the following Qur'ānic verse was revealed: "And Consult them in the matter" (3:159). He explains that the Prophetic biographies included many reports that establish the Prophet's practice of consulting with his Companions, such as the first Caliph, Abū Bakr al-Șiddīq (d. 634), the second Caliph, 'Umar b. Khattāb (d. 644), and others. ${ }^{38}$

The second distinguishing feature is that judgments in matters relating to state affairs evolve with changes in time and place. ${ }^{39}$ They are contingent upon social progress guided by contemporary knowledge ( ${ }^{i}$ lm). As al-Sanhūrī contended in the previous feature of state governance, these matters are subject to the knowledge that is derived from the rational faculty ('aql), they are necessarily subject to what is discovered from rules of change

\footnotetext{
${ }^{30}$ Al-Sanhūrī, 8.

${ }^{31}$ Al-Sanhūrī, 8.

${ }^{32}$ Al-Sanhūrī, 8.

${ }^{33}$ Al-Sanhūrī, 8.

${ }^{34}$ Al-Sanhūrī, 8.

${ }^{35}$ Al-Sanhūrī, 8.

${ }^{36}$ Al-Sanhūrī, 9.

${ }^{37}$ Al-Sanhūrī, 9.

${ }^{38}$ Al-Sanhūrī, 8.

${ }^{39}$ Al-Sanhūrī, 9.
} 
(qawānīn al-tatawwūr) through the social sciences. ${ }^{40}$ To al-Sanhūrī, rules relating to social interaction (al-ahkām al-dunyāwiyya) constantly evolve. These rules even changed over the course of the Prophet's lifetime. ${ }^{41}$ Al-Sanhūri provided a few examples, such as: the theory of abrogation in the Qur'ān; gradual prohibition on social habits such as drinking wine; and the plurality of Islamic legal schools. These examples, for al-Sanhūrī, are all traces of the evolution that was necessitated by public interest and compelling circumstances.

Al-Sanhūrī focused on another revealing example of social and legal change during the Prophet's lifetime to further make his point. ${ }^{42}$ He explained that when the Prophet migrated from Mecca to Medina, he was accompanied by a number of migrants (Muhājirūn) from Mecca. Upon arriving in Medina, they found themselves in an unfamiliar place without food or sustenance. Therefore, the Prophet united the Muslims of Medina (Anșār) with the migrants from Mecca (Muhājirūn) for five months after migrating to Medina. He designated ninety Muslims, forty-five from each group, as a union of brotherhood. This foundation of brotherhood established by the Prophet was based on mutual economic and psychological support and the principle of being inheritors to each other. ${ }^{43}$

Based on this union, al-Sanhūrī speculates that this system of brotherhood between residents in Medina and migrants from Mecca produced legal consequences similar in some respects to the system of adoption (nizām al-tabanī) in some European laws (al-sharāai al-ajnabiyya). He explains that the Prophet established a form of kinship based on a legal relationship (nasab qānūnī) through this system of brotherhood; then, he invalidated it and went back to kinship based on biological relations (nasab tabi $\left.i^{i}\right)$. These changes-to al-Sanhūrī-are examples of legal evolution prompted by economic needs, social circumstances, and public interest. ${ }^{44}$

After this presentation, al-Sanhūrī establishes that Islam is dīn wa dawla. This was a direct response to 'Alī 'Abd al-Rāziq's (d. 1966) ${ }^{45}$ book Al-Islām wa Ușūl al-Hukm (published in 1925, one year after the abolishment of the Ottoman caliphate), which claimed that the Prophet's message was limited to religious and spiritual affairs and that regulating daily affairs is not germane to the Prophet's message. ${ }^{46}$ 'Abd al-Rāziq's key claims in the book are that the

${ }^{40}$ Shalakany contends that al-Sanhūrî's invoking of the "social" was a mechanism to the modernization of Islamic law. To Shalakany, the "social" being understood as both a methodological choice as well as an ideological agenda. Shalakany, "Between Identity and Redistribution," 229-32.

${ }^{41}$ Al-Sanhūrī, "Al-dīn wa al-dawla fī al-Islām," 9.

${ }^{42}$ Al-Sanhūrī, 9.

${ }^{43}$ Al-Sanhūrī, 9.

${ }^{44}$ Al-Sanhūrī, 9.

45 'Alī 'Abd al-Rāziq, Al-Islām wa Ușūl al-Ḥukm [Islam and the principles of government] (Cairo: Maṭba'at Mișr, 1925). Also, al-Khilāfa wa Sulțat al-Umma, trans. 'Abd al-Ghanī Sanī (Cairo: Mațacat al-Hilāl, 1924). 'Alī 'Abd al-Rāziq's work was translated immediately into Ottoman Turkish. 'Alī 'Abd al-Rāziq, Islāmiyet wa Hukūmet [Islam and government], trans. 'Umar Riḍa (Istanbul: Kutuphane Sawdi, 1927). Two of the most important responses to 'Alī ‘Abd al-Rāziq's work are the following: Muhammad al-Khị̣r Ḥusayn, Naq̣̣ Kitāb al-Islām wa Ușūl al-Ḥukm [A critique of Islam and the principles of government] (Cairo: al-Mațba'a al-Salafìyya, 1925); Hukm Hay'‘at Kibār al-'Ulama $\bar{a}^{\prime}$ fi Kitāb al-Islām wa Usūl al-Hukm [The decision of the council of scholars regarding Islam and the principles of government] (Cairo: al-Mațba'a al-Salafiyya, 1925). For a more recent take on 'Alī 'Abd al-Rāziq's arguments, see Jamāl al-Bannā, Al-Islām Dìn wa Umma wa Layis Dìn wa Dawla [Islam is a religion and a global community, not a religion and state] (Cairo: Dār al-Fikr al-Islāmī, 2003). Unlike 'Abd al-Rāziq, al-Bannā argues that it is untenable to situate Islam in the modern nation state as Islamists imagine it due to the state's massive coercive apparatus and the nature of modern governance that might allow the state to completely control religion. Al-Bannā does not advocate for secularism or for Muslims to abandon politics; instead, he appears to emphasize the role of nonofficial organizations and deep-rooted social work in building and cultivating Islamic norms and social bonds of brotherhood beyond the modern nation-state's parameters of action and its mechanisms of coercion. For a history of the reception of the abolishing of the caliphate, see Mona Hassan, Longing for the Caliphate: A Transregional History (Princeton: Princeton University Press, 2016).

${ }^{46}$ Al-Sanhūrī, "Al-dīn wa al-dawla fī al-Islām," 10. Al-Sanhūrī dedicates some attention to refute both the normative and historical claims adopted by 'Abd al-Rāziq in his work. Al-Sanhūrī, Fiqh al-Khilāfa, 94-96. 
caliphate is not religiously obligatory and that Muhammad was a Prophet, not a king. To al-Sanhūrī, these claims are incorrect interpretations of the Prophetic message, and they represent an attempt to circumvent historical facts without proper evidence. ${ }^{47}$ If Muhammad was a Prophet in Mecca, al-Sanhūri declares, then he was the head of the community and founder of a "state" in Medina. Al-Sanhūrī does not see a problem in stating that the Prophet Muhammad was a king (malik) if the term is used to denote that he was the head of the Islamic government (al-hukūma al-Islämiyya) and a guardian (wali) over Muslims in their daily affairs-aside from the fact that he was their guide in their religious affairs also. ${ }^{48}$

Furthermore, al-Sanhūrī points out that when lawyers like him studied the science of figh, they discovered that Muslim jurists were aware of the importance of the distinction between matters of din and dawla. He explains that Muslim jurists divided Islamic law into chapters on rituals ( $i b \bar{a} \bar{d} \bar{a} t)$ and chapters on contracts and transactions (mu'āmalāt). For al-Sanhūrī, the chapters on mu'ämalät are the focus of modern state law (al-qānūn al-hadìth). If we are to preserve the classical meaning of the term $\operatorname{sharì}^{\top} a$, which combines both 'ibādāt and mu'āmalāt, al-Sanhūri proposed to create new terminology to indicate the shift of interest to studying exclusively the mu'ämalāt sections of fiqh. He suggested using the term Islamic law (al-qānūn al-Islämi) to refer to the chapters of mu'ämalät in the books of figh. ${ }^{49}$ This is the crux of al-Sanhūrì's project: the creation of an Islamic law that could be the basis for an Islamic public law (qānūn (āmm). This new Islamic law would include sections on transactions ( $\left.m u^{\prime} \bar{a} m a l \bar{a} t\right)$ from figh, some sections from legal theory (ușūl al-figh), and the section on political leadership (al-imāma) from theology ('ilm al-kalām). Overall, to al-Sanhūrī, Islamic law can be divided into two areas: (1) private law and (2) public law. Private law is concerned with rules that govern the relationship among individuals. He considers that the chapters on mu'ämalāt and personal status (ahwāl shakhsiyya) are part of private law. Public law, on the other hand, is concerned with rules that govern public authorities and the relationship between these authorities and the individuals within the polity. ${ }^{50}$

To al-Sanhūrī, this taxonomy of Islamic Law allows him to construct sub-divisions of law within these two main categories. He proposed that Islamic private law will include: civil law, civil procedures, and commercial law. On the other hand, Islamic public law will include: constitutional law, administrative law, and criminal law. This will also enable al-Sanhūrī to find foundations for public and private international Islamic law. The importance of adopting this taxonomy is to cope up with modern law and legal research, where legal science is fully developed. ${ }^{51}$ Al-Sanhūri is clear that this taxonomy of Islamic Law is not designed to dilute the shari ${ }^{\top} a$ in modern law so that it may lose its independence. Instead, it is meant to facilitate the comparison among these systems and promote legal research in shari ${ }^{-} a$ to catch up with modern law. ${ }^{52}$

This proposed taxonomy of public and private Islamic Law is contentious because it forces Islamic law into unexplored borrowed categories. However, al-Sanhūrī finds a basis for his taxonomy in legal theorists' distinction between claims of God (huqūq Alläh) and claims of the individual ( $h u q u \bar{u} q$ al-' $a b d$ ). He opined that claims of individuals are suitable to be considered within the domain of private law and claims of God to be placed with the domain of public law. Al-Sanhūrī uses these initial thoughts to argue that since Muslims have a law, they should then have an Islamic government. He envisioned a modern Muslim government to consists of three branches: legislative, executive, and judicial. ${ }^{53}$

\footnotetext{
${ }^{47}$ Al-Sanhūrī identifies 'Alī al-Rāziq by name in his book on the Caliphate. Al-Sanhūrī, Fiqh al-Khilāfa, 89-90.

${ }^{48}$ Al-Sanhūrī, "Al-dīn wa al-dawla fī al-Islām," 10.

${ }^{49}$ Al-Sanhūrī, 10.

${ }^{50}$ Al-Sanhūrī, 10.

${ }^{51}$ Al-Sanhūrī, 11. Al-Sanhūrī did not explain why he considered modern civil law systems to be "fully developed" in contrast to Islamic law. One clue might be that achieving legal modernity, for him, meant the state control over lawmaking.

${ }^{52}$ Al-Sanhūrī, 11.

${ }^{53}$ Al-Sanhūrī, 11.
} 
Al-Sanhūrī's articulation of these three branches of government is instructive to pinpoint how he inscribed Islamic law in the modern Egyptian state. Under the legislative authority, al-Sanhūrī emphasized that God is the legislator. However, God's commands and prohibitions can only be known through revelation. Revelation is given to prophets. Therefore, we can only know of God's will through the Prophet Muhammad. To al-Sanhūrī, the Qur'ān contains God's will and His message to His servants. ${ }^{54}$ Therefore, the Qur'ān should be the first source of legislation. And the prophetic Sunna-which explains the Qur'ān-should be the second source of legislation.

On the other hand, al-Sanhūrī stated that the daily affairs of individuals follow the development and changes in the social sciences. Following the cessation of revelation with the Prophet's death, it was imperative for Muslims to develop a third source of legislation that would guarantee that the rules regulating the daily lives of Muslims are suitable for each time and place. ${ }^{55}$ This third source of legislation-according to al-Sanhūrī-is the consensus of the Muslim community (umma). How could Muslim consensus become a law? Al-Sanhūri speculated that consensus in this context is not concerned with the agreement of independent Muslim scholars (al-mujtahidūn) in a particular time on a specific legal position, as is typically understood in uṣūl al-fiqh. For the modern Egyptian state, al-Sanhhūrī redefined consensus beyond its normative connotation, wherein only a class of jurists have such authority. He submitted that every Muslim could be a mujtahid if they are able, through knowledge, to reach such a degree of independent reasoning. ${ }^{56}$

Al-Sanhūrī theorized that consensus could become a law when a group of Muslims are deputized to act on the behalf of the umma. Unlike modern parliamentary councils, this deputyship is maintained through knowledge, not through elections. This group would have the authority to legislate according to the Qur'ān and Sunna. ${ }^{57}$ Al-Sanhūrī posited that the government in Islam is a government of scholars. The legislation in the Islamic government should be the exclusive authority of the jurists. This is a foundation of Islamic legal theory. For al-Sanhūrī, the caliph-who is at the top of the Islamic government-does not have the ultimate authority over legislation. ${ }^{58}$ However, he does partake in the legislative process in his capacity as a mujtahid, not solely due to his political qualifications. The sultan is only a deputy on behalf of the Umma. For al-Sanhūrī, the umma is the ultimate source of authority, and it is the deputy of God on earth (khalifa). Thus, the source of legislative authority in an Islamic government is the umma itself and it is not vested in one individual or a class of individuals. $^{59}$

In his discussion of the executive power, al-Sanhūrī stated that the executive authority in Islam is the government: specifically, a caliph-led government (hukümat al-khilāfa). ${ }^{60}$ This caliph-led government is marked by three key characteristics: (1) The caliph is not just a political ruler, but he is also the religious leader of Muslims. However, this religious role is limited to leading public prayers and rituals such as Hajj. To al-Sanhūrī, the term imām is used to refer to the religious duties of the caliph in his capacity in leading Muslims. By contrast, the label Amir al-Mu'minin (commander of the faithful) is used to refer to the political duties of the caliph. (2) The caliph in his executive authority should adhere to Islamic norms. He does not have to adhere to a particular legal school. As a mujtahid, he has the ability to consider the changes of time, circumstances, and places. He can demand from the independent jurists to agree on a maslaha for the benefit of the community-even if he disagreed with all the existing rules in the legal schools. For al-Sanhūrī, it is well

\footnotetext{
${ }^{54}$ Al-Sanhūrī, 11.

${ }^{55}$ Al-Sanhūrī, 11.

${ }^{56}$ Al-Sanhūrī, 11.

${ }^{57}$ Al-Sanhūrī, 11.

${ }^{58}$ Al-Sanhūrī, 11.

${ }^{59}$ Al-Sanhūrī, 12.

${ }^{60}$ Shalakany states that al-Sanhūrīs proposal regarding the future of the caliphate appears in his Le Califat. Shalakany, "Between Identity and Redistribution," 213.
} 
established that the consensus of mujtahids is a legitimate source of legislation. (3) The authority of the caliph should be recognized by the Muslim world. The unity of God is the bedrock of the Islamic state. The unity of Islam should necessitate the existence of one caliph. Al-Sanhūrī calls this scenario a complete caliphate (al-khilāfa kāmila). ${ }^{61}$

However, al-Sanhūrī contends that since historical circumstances may oblige Muslimswhose unity has been unattainable-to be divided into different nations, then each would have local governments, thus necessitating the existence of multiple caliphs. In this scenario, the caliphate is incomplete (khilāfa ghayr kämila). Al-Sanhūrī projected that having one caliph under which Muslims can develop a single unified government appears to be impossible as a practical matter. He proposed that Muslim governments might reach an understanding to form a League of Muslim Nations to lead local Muslim governments. ${ }^{62}$ The league would be the institution of the caliphate (ha'yat al-khiläfa), in which an independent office could be dedicated to address the religious affairs of Muslims. ${ }^{63}$

As for the judicial authority, al-Sanhūri stated that it used to be part of the executive branch. The caliph used to combine both authorities. He is the one who hires and fires judges and could adjudicate some issues himself. The Prophet and the rightly guided caliphs after him did adjudicate cases among people. Upon the expansion of Muslim lands, caliphs delegated judges to adjudicate among people in the provinces and garrison cities. The judiciary since then had gradually become more independent from the power of the executive. ${ }^{64}$

After this presentation of a potential rapprochement between Islamic law, its historical institutions, and the emerging modern nation state apparatus in Egypt, I glean three main observations from al-Sanhūrī's project. First, he theorized a relationship between the modern Egyptian state and Islamic law, where the matters of din and 'ibādāt are the exclusive domain of Muslim theologians. He stressed that there is no room for the state to encroach on these matters. ${ }^{65}$ Al-Sanhūrī's recalibrations of the domains of din and dawla were construed in the secondary literature as an indication of al-Sanhūrî's secularism. ${ }^{66}$ Amr Shalakany, for example, argued: "Sanhuri asserts already in the avant propos the fundamental distinction between 'sacred' and 'temporal' aspects of Islam, and unequivocally locates his study of Islamic law in the realm of the latter." ${ }^{17}$ He claimed: "Both Sanhuri and Nasser were secularists: both were committed to a fundamental distinction between the religious and the temporal, and both awarded exclusivity to the temporal in the public sphere." ${ }^{68}$ I am not convinced by Shalakany's collapse of the obvious difference between al-Sanhūrī and Nasser. After all, al-Sanhūrī stressed the essential role of Islam in any form of political governance in Muslim societies, rejecting 'Alī 'Abd al-Rāziq's assertions about the caliphate and emphasized the importance of Muslim political solidarity evidenced by his work on the caliphate.

Second, al-Sanhūri transforms the meaning of the caliphate by deploying its inherent potency for a collaborative political order among Muslim nations in the early twentieth

\footnotetext{
${ }^{61}$ Al-Sanhūrī, "Al-dīn wa al-dawla fī al-Islām," 13.

${ }^{62}$ Shalakany suggests that this proposition by al-Sanhūrī was "was facilitated by his anti-formalist appreciation of the nature of Islamic law in general, and the caliphate in particular." Shalakany, "Between Identity and Redistribution," 213.

${ }^{63}$ Al-Sanhūrī, "Al-dīn wa al-dawla fī al-Islām," 13.

${ }^{64}$ Al-Sanhūrī, 13.

${ }^{65}$ These categories appear in al-Sanhūrì's second doctoral dissertation, Le Califat. Shalakany contends that these categories allow al-Sanhūrī to "propose the secular development of the caliphate as a modern League of Nations, an institution of politics, not religion, based on a cultural, rather than cultist, history of Islam." To Shalakany, "Le Califat is above all an exercise in nationalist activism." Shalakany, "Between Identity and Redistribution," 212.

${ }^{66}$ Enid Hill, "Al-Sanhuri and Islamic Law [Part 2]," 184. Shalakany posits a similar position: "Both Sanhuri and Nasser were secularists: both were committed to a fundamental distinction between the religious and the temporal, and both awarded exclusivity to the temporal in the public sphere." Shalakany, "Between Identity and Redistribution," 241.

${ }^{67}$ Shalakany, "Between Identity and Redistribution," 211.

${ }^{68}$ Shalakany, 241.
} 
century. Al-Sanhūrī installs the collective of the community-the umma-as the true caliph: the sole locus of authority and legitimacy. Therefore, it is through its will and emancipatory politics that Muslims can form political institutions that can sustain their aspirations for unity and strengthen their resilience for independence from colonial rule.

Finally, al-Sanhūrī was the first to introduce the distinction between public and private law in his proposed codified Islamic law. On public law, al-Sanhūrī laments the absence of rules that govern the principles of political legitimacy in Islamic jurisprudence by blaming the tyrannical governments of the past. He emphasizes that the objective of these governments was to suppress any juristic movements that would establish political rule on the principles of political freedom and democratic public rights. Al-Sanhūrì's goal from this notion was to develop a theory of political legitimacy that goes beyond the figh tradition, which was limited in its scope to the mere legitimate exercise of power. ${ }^{69}$

\section{A Restatement: Al-Sanhứrī on Islamic Courts}

In 1936, al-Sanhūrī published an article titled "Wujūb tanqīh al-qānūn al-madanī al-mișrī wa 'alā ayy asās yakūn hadhā al-tanqīh" in Majallat al-Qānūn wa al-Iqtișād. ${ }^{70}$ In it, he presented three key proposals as part of a roadmap for extensive revisions of civil law (al-qānūn al-madanī) in Egypt. Compared to his previous commitments in 1929, al-Sanhūrī made a set of revisions-restatement of his previous arguments-regarding the role of Muslim jurists and Islamic legal institutions in the emerging Egyptian state.

First, al-Sanhūrī rejected the legal wisdom of early twentieth-century Egypt, which had enabled a careful balance between codified civil law that governed commercial transactions and uncodified norms of Islamic law that governed personal status laws, endowments, and a set of contractual agreements. This balance maintained the coexistence of Islamic courts, religious tribunals for Jews and Christians, and state secular courts. ${ }^{71}$

Second, al-Sanhūrī called for a complete codification of the entire legal domain in Egypt (al-taqnin al-kāmil). ${ }^{72}$ He called for the codification of all spheres of law and insisted that it should be a comprehensive code just as any other civil code in Europe. Al-Sanhūrī emphasized that in the process of this codification, personal status law would not borrow from Western legislation (al-tashri' $\bar{a} t$ al-gharbiyya). He maintained that the new legislated code (al-tashrī al-jadìd) would be based solely on Islamic law (al-sharī'a al-Islāmiyya). Al-Sanhūrī introduced a caveat that the proposed new code would be made suitable to apply to all Egyptians, including non-Muslims, in their commercial and personal status laws. ${ }^{73}$ Al-Sanhūrī argued that such a unified legal code would respect all religious beliefs and would not violate any of them. ${ }^{74} \mathrm{He}$ asserted that the rules that would be codified from the shari' $a$ should be carefully selected so that they can be applicable to all Egyptians, Muslims and non-Muslims. However, if necessary, al-Sanhūrī explained, a codification of specific rules to be applicable only to non-Muslims should be devised to fill any gaps. ${ }^{75}$

\footnotetext{
${ }^{69}$ Mohammad Fadel, "Political Legitimacy, Democracy and Islamic Law: The Place of Self-Government in Islamic Political Thought," Journal of Islamic Ethics 2 (2018): 59-75, at 74.

${ }^{70}$ Al-Sanhūrī, "Wujūb tanqīh al-qānūn al-madanī al-mișrī wa 'alā ayy asās yakūn hadhā al-tanqīḥ" [The necessity of revising Egyptian civil law and on what basis it could be achieved], Majallat al-Qānūn wa al-Iqtiṣād 6, no. 1 (1936): 3-144.

${ }^{71}$ Al-Sanhūrī, "Wujūb tanqīh al-qānūn al-madanī al-mișrī," 59-60.

${ }^{72}$ Al-Sanhūrī, 60.

${ }^{73}$ Al-Sanhūrī, 60.

${ }^{74}$ Wood maintains that "the idea of a hierarchical and interlocking system of principles, created by a science of jurisprudence that itself could be a source of law in addition to custom and legislation, would find its way into Egyptian legal literature during the interwar years as a result of Egyptian jurists' exposure to twentieth-century French-language doctrinal literature that had internalized German approaches and theories." Wood, "Al-Sanhuri's Theory of Rights in Islamic Jurisprudence," 868.

${ }^{75}$ Al-Sanhūrī, 60.
} 
Third, al-Sanhūrī claimed that the complete integration of personal status laws into the civil law jurisdiction did not mean "integrating"" Islamic Courts (al-mahākim al-shar'iyya), Religious Tribunals (al-majālis al-milliyya), and Probate Councils (majālis hasbiyya) into the National Courts (al-mahākim al-ahliyya). However, he made sure to note that this "integration" of all courts is the wish of every patriotic Egyptian who aspires for judicial reform and it is a necessary process. ${ }^{77}$ This unification proposal is a culmination of debates that started in the late nineteenth century and intensified after World War I. In April 1930, Rashīd Ridāa (d. 1935)-the founder of the famous journal Al-Manār-published a piece in Majallat al-Muhāmāh al-Shar'iyya on the significance of distinguishing between Islamic and National Courts and their treatment of the Islamic legal tradition. The key argument pursued by Ridā was that, unlike for the National Courts, the legal issues that fall within the limited jurisdiction of Islamic courts are not subject to the prerogative of the political authorities because they are intimately associated with religious and doctrinal matters with stipulated textual evidence. In Ridā's estimation, despite the expanding jurisdiction of National Courts, the legal matters that they address (such as criminal and financial disputes) are open to policy considerations and independent reasoning (ijtihād). In short, the overwhelming gist of Rida's writings in early twentieth century Egypt concerns the uncertain fate of Islamic Courts. It was clear to Riḍa that calls to unify the judiciary (tawhìd al-qad $\left.\bar{a}^{3}\right)$ were only a pretext to abolish Islamic courts. ${ }^{78}$

Al-Sanhūrī affirmed that the goal of integrating and codifying Islamic personal status law was not to sideline the authority of the shari' $a$; instead, he asserted that such codification would be an extension of the authority of the shari' $a$ not only to personal status law but also to commercial transactions within the civil law. ${ }^{79}$ Thus, al-Sanhūrī viewed Islamic courts as temporary institutions that should be eventually subsumed under National Courts (al-mahākim al-ahliyya). ${ }^{80}$ I propose that al-Sanhūrî's claim here should be read as both a manifestation of his commitment to an understanding of the social function of law and as an effective maneuver that allowed him to address mounting criticism of the fate of Islamic courts. These claims by al-Sanhūrī about codification of personal status law have been couched in the scholarly literature as evidence of "Islamization" of Egyptian law. Enid Hill, for instance, has proposed that al-Sanhūrìs major aim for the revisions of the civil law "was to make Egypt's civil law more Islamic." ${ }^{81}$ I contend that it is precisely this narrative that shields al-Sanhūrī and his project from scrutiny and critical engagement. It deliberately masks serious ruptures in Egyptian legal history while simultaneously justifying the erasure of Islamic legal institutions and religious tribunals for non-Muslims. It is a misreading of al-Sanhūrīs project to consider his reliance on the Islamic legal tradition-among other sources-as an "islamicisation of Egyptian law."

Al-Sanhūrī asserted that it is an erroneous impression to maintain that Islamic law (al-shari' a al-Islämiyya) can be found only through the process of discovery in authoritative Muslim juristic works. He explained that codifying shari $a$ is not a difficult matter, elaborating that "codifying Islamic law was officially done by the Turks in the famous Mecelle [the Ottoman civil code] and a similar project was completed in Egypt by Muhammad Qadrī Pasha (d. 1928), in which he codified Islamic norms in personal status law, commercial

\footnotetext{
${ }^{76}$ Al-Sanhūrī, 60. He uses the Arabic word damj, but in practice, it is ilghăc (abolishing).

${ }^{77}$ Al-Sanhūrī, 60.

${ }^{78}$ See Muhammad Rashīd Riḍā, "Al-Ḥukm fĩ al-bilād al-Islāmiyya: 'ilāqit al-mahākim al-shar'īyya wa al-ahliyya bil-sharī'a al-islāmiyya" [Judicial rule in Islamic countries: The relationship between Islamic and National Courts and Islamic law], in Majallat al-Muhamāh al-Shar'iyya, ed. Muharram Fahīm, year 1, no. 7 (1929): 574-81, at 575.

${ }^{79}$ Al-Sanhūrī, "Wujūb tanqīh al-qānūn al-madanī al-mișrī," 60. Al-Sanhūrī makes a similar claim in his commentary on the Egyptian civil law, stating that Islamic law is an official source of civil law, after legislative enactments and custom: 'Abd al-Razzāq al-Sanhūrī, Al-Wașịt fi Sharh al-Qānūn al-Madanī [A commentary on Egyptian civil law], 10 vols. (Beirut: Dār Ihyā̄' al-Turāth al-'Arabī, n.d.), 1:45.

${ }^{80}$ Al-Sanhūrī, "Wujūb tanqīh al-qānūn al-madanī al-mișrī," 60.

${ }^{81}$ Hill, "Al-Sanhuri and Islamic Law [Part 1]," 35.

${ }^{82}$ Hill, "Al-Sanhuri and Islamic Law [Part 2]," 183.
} 
transactions, and endowments based on Hanafī jurisprudence." ${ }^{83}$ Al-Sanhūrī pointed out that Egyptian legislators had already codified some of the Islamic procedural rules that were integrated into the ordinances of Sharīa courts. ${ }^{84}$ He contended that in the proposed process of rewriting the civil law in Egypt, the drafters should choose from the most suitable positions from the Islamic legal works, without adhering to a particular legal school. The codification of personal status law would thus not only be just another code but also, and more significantly, a comprehensive legal reform. ${ }^{85}$

Aware of the serious consequences of his proposal, al-Sanhūrī emphasized the importance of separating the prospects of creating a unified and comprehensive civil code from the idea of unifying all courts within a single court system. However, in practice, al-Sanhūrī's proposal sealed the fate of the Islamic courts. He saw the emergence of a nationalized court system as inevitable due to the importance of establishing a unified civil code as an expression of Egyptian sovereignty and independence. ${ }^{86}$ Al-Sanhūrī consistently compared his proposal for a unified civil code to similar efforts in France and Italy as an expression of their sovereign national will and a process to avoid conflicts and disputes among different legal bodies within the country. It is important to underline that al-Sanhūri viewed National Courts (al-mahākim al-ahliyya) as the only recognized state courts (al-mahākim al-'ämma) which he intended to function under a unified civil code and thus to rebrand as "Egyptian National Courts" (al-mahākim al-mișriyya). He stressed that all other courts such as Mixed and Islamic courts are merely provisional courts (mahākim istithnā'iyya), which eventually would become part of the Egyptian National Courts (al-mahākim al-mișriyya) ${ }^{87}$

Leonard Wood offers a detailed account of the intellectual context-namely, European style comparative law-that helped al-Sanhūrī to develop a practical theory of modern Islamic private law. ${ }^{88}$ Wood focused his analysis on al-Sanhūrī's final comparative legal work, Mașādir al-Haqq fì al-fiqh al-Islāmī (Theory of rights in Islamic law). ${ }^{89} \mathrm{He}$ explains that al-Sanhūrì's Theory of Rights is "rarely analyzed for what it reveals about the juridical method of al-Sanhūrī and similarly minded jurists of his age." 90 Wood argues that al-Sanhūrīs Mașādir al-Haqq fì al-fiqh al-Islämi was the "material revision of the theory and methods of Islamic jurisprudence in the modern era." ${ }^{91}$ Wood claims that al-Sanhūri embraced the role of an independent Muslim jurist (mujtahid), who addressed questions about modern Islamic private law on his own authority. ${ }^{92}$

Wood elaborates that al-Sanhūri used comparative law to "guide the formation of a practical theory of modern Islamic private law and, in the process, to explain how Arab civil codes were consonant with Sharia, even though their articles were borrowed from European codes." ${ }^{93}$ This approach was deployed by al-Sanhūrī to argue that the Egyptian

\footnotetext{
${ }^{83}$ Al-Sanhūrī, "Wujūb tanqīh al-qānūn al-madanī al-mișrī," 60.

${ }^{84}$ Al-Sanhūrī, 60.

${ }^{85}$ Al-Sanhūrī, 60. For a comprehensive overview of the 'Ulamā's reception and responses to al-Sanhūrì's project, see Tarek Elgawhary, Rewriting Islamic Law: The Opinions of the 'Ulamā' towards Codification of Personal Status Law in Egypt (Piscataway: Gorgias Press, 2019). Elgawhary records the 'Ulamā' engagement with al-Sanhūrī in detail in chapter 4, 157-202.

${ }^{86}$ Anver Emon provides important insights on the debates surrounding codification in Islamic legal studies, presenting a compelling narrative about how an (unarticulated) ideology about legal form and the state drives the field in particular directions. Anver M. Emon, "Codification and Islamic Law: The Ideology behind a Tragic Narrative," Middle East Law and Governance 8, nos. 2-3 (2016): 275-309.

${ }^{87}$ An unnumbered footnote in al-Sanhūrī, "Wujūb tanqīh al-qānūn al-madanī al-mișrī," at 63.

${ }^{88}$ Wood, "Al-Sanhuri's Theory of Rights in Islamic Jurisprudence," 859.

${ }^{89}$ 'Abd al-Razzāq al-Sanhūrī, Mașādir al-Haqq fì al-fiqh al-Islāmī: Dirāsa Muqārana bi al-Fiqh al-Gharbī [Theory of rights in Islamic law: A comparative study with Western jurisprudence] 2 vols. (Beirut: Mu'asasat al-Tārīkh al-'Arabī wa Dār Ihȳā' al-Turāth al-'Arabī, 1997).

${ }^{90}$ Wood, “Al-Sanhuri's Theory of Rights in Islamic Jurisprudence," 859.

${ }^{91}$ Wood, 874.

${ }^{92}$ Wood, 874.

${ }^{93}$ Wood, 892.
} 
Civil Code of 1948 and other Arab civil codes were consonant with Islamic legal tradition. ${ }^{94}$ Wood contends that al-Sanhūrī's "methodology and theory of Islamic jurisprudence faded from prominence not because they definitely constituted a weaker and less defensible approach from the standpoint of Islam, but rather because political, cultural, and religious forces that became prominent in Egyptian society and the Arab world pushed law and legal thought in different directions to serve competing goals." ${ }^{95}$ Wood sees the future of al-Sanhūrï's project to have been "cut short by the Arab nationalist revolutions and the subsequent rise in the cultural and religious influence of the Gulf states."

I find Wood's intervention compelling. He provides a detailed narrative of the intellectual genealogy of al-Sanhūrī's legal thought. Wood is correct to point out that al-Sanhūrī's Mașādir al-Haqq fì al-fiqh al-Islāmī "could be understood as one of al-Sanhūrī's various expositions that sought to explain and defend the 'Islamicity' of the new Arab civil codes." ${ }^{27}$ I am not as certain as Wood about the success of this strategy and its rhetoric, however. Al-Sanhūrī's need to defend the "Islamicity" of his project should be understood in the context of the European sources of the civil code and its devastating consequences on the standing Islamic legal institutions, scholars, judges, and lawyers after World War I. After the 1930s, al-Sanhūri did not see a future for the institutional presence of Islamic law outside what he voluntarily admits would-be Egyptian civil law. In addition, there are material reasons inherent to al-Sanhūrī's project that should be considered in the assessment of the failure of the project to take firm roots, key among them: (1) the fierce rejection of al-Sanhūrì's codification project by a wide coalition of the educated class, including some of al-Sanhürì's colleagues who studied in France; (2) the policy repercussions for Islamic legal institutions, such as courts, in light of al-Sanhūrī's insistence on complete codification of all spheres of law and unification of courts.

In addition, I am ambivalent about Wood's framing of al-Sanhūrī's engagement with Islamic law, or that al-Sanhūrî's efforts to include aspects of Islamic jurisprudence in the Egyptian civil law made him a mujtahid. ${ }^{98}$ This assessment is based on the understanding that al-Sanhūrì's re-articulation of some Islamic legal norms to fit civil law strictures was an exercise in Islamic legal thought. I contend that Islamic law appears, in al-Sanhūrī's writings, as an effective instrument and justificatory tool that allows him to both commit to and deviate from certain positions in the codes that he consulted for the formation of his codification project. In these efforts, al-Sanhūrī reveals himself to be the sole arbiter of the acceptability of Islamic legal positions and their authoritativeness-a sign of his intellectual courage.

\section{Unification of Courts: From a Colonial Policy to a Nationalist Aspiration}

The unification of Egyptian judicial bodies (tawhìd al-qad $\bar{a}^{\jmath}$ ) was a concern for British colonial officers in the late nineteenth century. Since the 1890s, the British judicial advisors at the Ministry of Justice (wizärat al-haqqaniyya) played a central role in shaping courts in Egypt through the careful rearrangement of legal education, leading committees that selected students for the Khedival Law School, serving as judges for civil courts, and shaping procedural law and the jurisdictional authority of Islamic courts. On April 4, 1896, Majallat al-Huqūq (Al-Hocouc) published a front-page piece on the unification of the Egyptian judiciary. The editor of Al-Huqūq, Emin Schemeil (d. 1897), identified three central challenges to the reforms championed by the British judicial advisor, Sir John Scott (d. 1904), who had assumed this role in 1891. First, unification of the judicial system under a single law: Schmeil argued

\footnotetext{
${ }^{94}$ Wood, 859.

${ }^{95}$ Wood, 894 .

${ }^{96}$ Wood, 857.

${ }^{97}$ Wood, 876.

${ }^{98}$ Wood, 871.
} 
that the existence of diverse judicial bodies with separate procedural and legal norms, namely, National, Mixed, Islamic, consular, and patriarchate courts, was an obstacle for the reform agenda of establishing a single court system under a single law. Second, unification of civil law: the editor maintained that law must be unified in Mixed and National courts, a challenge that the Egyptian nationalists, with British support, achieved by the midtwentieth century. Third, a comprehensive civil code (al-shari' $a$ al-madaniyya): Schmeil stressed that there is a single legal system in every modern nation, and it cannot differ based on one's legal school, sect, or religious backgrounds because law pertains to all individuals. Schmeil claimed that a secular state legislator (al-shäric al-madanī) is necessarily focused on preserving and expanding secular state laws-as opposed to religious laws (al-huqūq al-dīniyyah)-in order to preserve social bonds among individuals in a single polity and maintain relations among states. ${ }^{99}$ He stressed the necessity, if not the inevitability, of the unification of laws in Egypt; however, simultaneously, he lamented that such endeavors would take time to materialize. ${ }^{100}$ Egyptian nationalists and the secular legal elite in the early twentieth century embraced this policy of unification of laws and courts as a concomitant condition for achieving Egyptian independence and statehood.

These debates reveal that the secularization of law in Egypt had been achieved partly through procedural and structural reconfiguration of Islamic courts by limiting their jurisdiction, diminishing their status, undermining their financial resources, and more seriously, not enforcing their decisions. ${ }^{101}$ Interestingly, Schmeil insisted that limiting the jurisdiction of Islamic and Christian courts to purely "religious matters" (al-qism al-dini) was a priority, and that religious courts presented a challenge for the judicial reform spearheaded by British colonial officials. The policy to limit the jurisdiction of Islamic courts was in fact adopted a few months later in the new Khedival procedures for Islamic courts issued on May 27, 1897. ${ }^{102}$

These arguments pursued by British colonial officers and the Egyptian secular legal elite on the jurisdictional authority of Islamic courts are consistently discussed within a binary that (mis)defines the religious (al-dinī) and secular (al-madanī) domains. Christian, Islamic, and Jewish courts are squarely placed in the al-dini category. A recurrent term in Majallat al-Huqūq is the word madani to indicate the nonreligious (state) law (ghayr al-dīnì). ${ }^{103}$ This term in Arabic conveys a particular value judgment of the place of religion in society. The madani is not merely a state law enacted by a secular legislator. It is a marker for a

\footnotetext{
99 “Tawhīd al-Qaḍ̄ā”" [Unification of courts], Al-Hocouc: Majalla Huqūqìyya, Qadā’iyya, Tārīkhìyya, Adabìyya, year 11, no. 14 (1896): 105-07, at 106.

100 “Tawhīd al-Qaḍā̄," 107.

${ }^{101}$ Majallat al-Ahkām al-Shar'iyya reported that no more than 10 percent of the Islamic courts' judgments are enforced: “Al-Tanfïdh al-Tanfïdh!” [Enforcement!], Majallat al-Aḥkām al-Shar'iyya, year 2, no. 2 (1903): 35-41, at 36.

102 The British judicial advisor, Malcolm McIlwraith (d. 1941), the immediate successor of Sir John Scott, wrote in his report in 1898 ,
}

\begin{abstract}
these Courts have displayed a marked disinclination to depart in any way from their traditional methods of procedure. As an instance of this pertinacious conservatism, I may mention the circumstance that though the regulations provide that each case shall be conducted regularly step by step, until its conclusion-statement of claim, defence and judgment-in order that, so far as possible, each several case may be disposed of in rotation, the cadis prefer to hear the statement of claim in five, ten, twenty cases, one after the other, and then adjourn till a future sitting for the hearing of a corresponding string of defences. It is difficult to imagine how, under such circumstances, justice can be done in any particular case, or indeed what security there is that the right defence will be attributed to its respective statement of claim. It seems as if such a system must inevitably result in practice in an inextricable muddle. However, as far as may be, the Ministry of Justice endeavours to exercise a certain supervision over these Courts by means of its special inspectors, who periodically visit the different Mehkemehs in turn and make reports.
\end{abstract}

Reports for the Years 1898-1902, prepared by the Judicial Advisor (Cairo: National Printing Department, 1904), 7-8.

103 "Tawhīd al-Qaḍā'," 106. 
civilizing mission and a superior legal progress, as understood at the time. In this framework, what was dubbed al-shari'a al-madaniyya (civil law) took priority over religious law (al-huqūq al-diniyya). ${ }^{104}$ Salaymeh shows how secular framing of the law dominates Islamic legal studies now, much as it dominated the historical debates around the place of religious courts in the Egyptian judiciary. She argues that "secularism converts legal traditions into religious law." Salaymeh defines religion as "non-secular" and stresses that the modern category of religion is not "transhistorical, or universal, or neutral." ${ }^{105}$ I find Salaymeh's framing very helpful for the historical Egyptian context. I suggest that this framing could be more generative by taking into consideration other potential vernacularisms of the secular (al-madanī).

The unification of courts in Egypt materialized after Islamic courts were officially abolished three years after the military coup of 1952. With its nationalist agenda, the coup leaders abolished the constitutional monarchy and established a new republic. On December 23, 1955, a decree was issued to dissolve the Islamic courts, after Gamal Abdel Nasser (d. 1970) launched a defamation campaign against two prominent Muslim judges in Egyptian newspapers. The explanatory memorandum of the Law 462 for 1955, which officially abolished Islamic courts and religious tribunals in Egypt, based this decision squarely on the state's "complete and absolute sovereign power" (siyādat al-dawla tāmma wa muțlaqa). ${ }^{106}$ This memorandum reveals the radical shifts in the conceptual landscape and the meaning of the Arabic phrases and their intended Eurocentric formations circulating in Al-Sanhūrī's project-such as siyāda (sovereignty), dawla (national state), ummah (nation), sulța (sovereign power of the state), and ijtihād (utilitarian reasoning)-from their articulation and manifestations under Ottoman and Khedival governance in Egypt. ${ }^{107}$

At its core, the abolition of Islamic courts in 1955 demonstrated that the emerging position among the Egyptian secular, political, and legal elite ceased to support the existence of Islamic legal institutions and their modes of legal reasoning and practice. ${ }^{108}$ For example, in the 1930s, Ahmad Șafwat Bik (Bey), chief justice of the Appellate Court in Alexandria, opposed the existence of separate religious courts for Jews and Christians. He advocated instead to enact a set of laws to regulate issues of marriage and divorce for non-Muslims within the secular national court system. Șafwat also proposed the integration (damj) of Islamic courts into the secular National Courts as a religious circuit (dā'ira shar'iyya). ${ }^{109}$ On the basis of his confidence in the inevitable shift to legal modernity, Șafwat produced a set of arguments and interpretations of history, religion, and law to assert the political and legal complications of religious courts and the urgency of their abolition for the sake of the nationalist legal project. ${ }^{110}$ This development is supported by the logic of civil law that dominated the legal thinking and shaped the structures of Egyptian law. This kind of institutional and theoretical framing of law and legal reasoning in early twentieth-century Egypt not only shaped the emerging legal practice, but also made Islamic courts' existence unthinkable and their practice impossible.

\footnotetext{
104 “Tawhīd al-Qaḍā'," 106.

105 Salaymeh, "Decolonial Translation," 262.

${ }^{106}$ Ahmad Muhammad Ibrāhīm, Majmū'at Qawānīn al-Aḥwāl al-Shakhṣiyya [The complete compilation of personal status laws] (Alexandria: al-Dār al-Mișriyya li-al-Ṭibā'a wa al-Nashr, n.d), 9.

${ }^{107}$ Safran, "The Abolition of the Sharī'a Courts in Egypt II," 132-33.

108 Shalakany presents a sympathetic history of these secular legal elite who, in his estimation, were key in pushing for the abolition of Islamic courts, religious tribunals, and private endowments. He paints these efforts as an example of the struggle for "judicial and legal reform." Amr Shalakany, Izdihār wa Inhiyār al-Nukhbah al-Qānūniyya al-Mișriyya, 1805-2005 [The flourishing and decline of the Egyptian legal elite] (Cairo: Dār al-Shurūq, 2013), $239-72$.

${ }^{109}$ Ahmad Șafwat Bik (Bey), Qaḍ̄̄a al-Ahwāl al-Shakhșiyya li’l Țawā'if al-Milliyya [Judicial rules of personal status law for non-Muslims] (Cairo: Mațbacat Wahba, 1948), A-B.

${ }^{110}$ Șafwat, Qaḍā’ al-Ahwwāl al-Shakhșiyya, 113-17.
} 


\section{Civil Law: Transplantation of a Legal System}

Al-Sanhūrī was a gradualist. Civil law, for him, opened up the country to a new mode of justice and familiarized its population with a new court system. Al-Sanhūrī's keen interest in French civil law appears to be related to the latter's history and impact in the Muslim world. ${ }^{111} \mathrm{He}$ articulated three main reasons why French civil law was more compelling: (1) French civil law differentiated between legislation and jurisprudence as two spheres of law that do not overlap; (2) French code did not adopt rigid positions on legal theories and philosophical schools and avoided redundancy; ${ }^{112}$ (3) the legal language of the French codes is flexible, allowing them to address real life circumstances and their continuous evolution. $^{113}$

In the 1930s, al-Sanhūrī was no longer wedded to the old French code; instead, he was deeply invested in codification as a legal technique that must be mastered and deployed. In 1936, Al-Sanhūrī published another important article on the future of the Iraqi civil code, tellingly titled "Min Majallat al-Aḥkām al-'Adliyya ilā al-Qānūn al-Madanī al-'Irāqī" (From the Mecelle to the Iraqi civil law). Al-Sanhūri emphasized the unique significance of the Hanafi school and its history and social significance in Iraq and insisted that the shift from the Mecelle to his proposed Iraqi civil law was not an attempt to displace Islamic law and Hanafi jurisprudence. He maintained that the proposed Iraqi civil law was new only in terms of its title and asserted that Iraqi civil law already existed in the form of the Mecelle, which needed some improvements to meet the styles and legal form (siyāgha) of new codes at the time. Al-Sanhūri argued that the Mecelle would benefit from better organization, arrangement, and adjustments entailed by legal modernity. He emphasized the continuity of the proposed Iraqi civil code with previous legal traditions. Thus, he advanced the claim that the new code was both connected to the past and well positioned to meet the demands of the future. ${ }^{114}$

Al-Sanhūrī explained that codification is not a modern movement but a technique that permeates ancient legal traditions. ${ }^{115}$ He cited the examples of the Hammurabi code, Code of Justinian, and church law. Al-Sanhūrī considered the codification movement of the late nineteenth and early twentieth century as the latest phase in the long history of codification. A central theme in al-Sanhūrì's enthusiasm for codification comes down to its potent political utility. In his passionate argument for the promulgation of an Iraqi civil law, al-Sanhūrī maintained that codification is not pursued as a project in itself. Instead, he presented it as an effective legal instrument and a template to imprint with local Iraqi legal traditions and Islamic law. He asserted that it would be imprudent to dismiss the rich legal history of Iraq and transplant a wholesale foreign code, thus living dependent on other nations and pleading to benefit from their traditions. ${ }^{116}$ Al-Sanhūrī saw codification of Islamic law as a purely legal technique that would enable it to exist outside the framework of figh. This process, he argued, will keep the status of Islamic law within new emerging legislative and judicial bodies. ${ }^{117}$

Moving to the Egyptian context, al-Sanhūrī saw the historical introduction of civil law in the Mixed and National Courts as a key improvement compared to the state of affairs before its introduction. Restating familiar tropes of some nationalist historians, al-Sanhūrī claimed that the judiciary was in chaos, laws were obscure, and justice was rarely delivered before

\footnotetext{
${ }^{111}$ Al-Sanhūrī showed no interest in English common law. He maintained that it was alien in Egypt, and he was not familiar with it. Al-Sanhūrī, "Wujūb tanqīh al-qānūn al-madanī al-mișrī," 78.

${ }^{112}$ Al-Sanhūrī emphasized that if a codification project depends upon a single legal school, it would result in rigidity and stalled development. This gives partial context to his rejection of the Mecelle or Qadrī Pasha's code because they were based exclusively on the Ḥanafī school. Al-Sanhūrī, "Wujūb tanqīh al-qānūn al-madanī al-mișrī," 78.

${ }^{113}$ Al-Sanhūrī, “Min Majallat al-Ahkām al-`Adliyya ilā al-Qānūn al-Madanī al-'Irāqī,” 278.

${ }^{114}$ Al-Sanhūrī, 271.

${ }^{115}$ Al-Sanhūrī, 271-72.

${ }^{116}$ Al-Sanhūrī, 269-71.

${ }^{117}$ Al-Sanhūrī, 269-71.
} 
the introduction of codified law. ${ }^{118}$ In his estimation, the introduction of civil law brought about order and gave Egypt a roadmap to reform. ${ }^{119}$ Unlike jurisprudence-which falls within the domain of legal experts-al-Sanhūrī viewed legislation as an exercise exclusive to the sovereign authority. Thus, a legal command or a ruling, in a strict sense, would fall squarely within the domain of legislation. ${ }^{120}$

The future of Islamic law under government-led intense codification efforts has become a major concern among Muslim judges and intellectuals since the 1920s. One of the most significant arguments for adhering to Islamic law was articulated by Muhammad Sulaymān 'Annāra (d. 1936), a deputy to the chief justice of the Islamic Supreme Court in Cairo. 'Annāra gave a series of lectures in 1936, "Bi'ayy Shar' Nuhkam?" (By which laws should we be governed?). ${ }^{121}$ The central claim in his lectures is that the laws that have historically governed Egypt were deeply intertwined with local customary practices and specific social conditions. Thus, 'Annāra argued that any serious attempt to maintain a sense of nationality (wataniyya) among Egyptians requires that any introduction of new laws should be responding to local forms of justice and indigenous legal traditions. 'Annāra was not concerned about the similarities among Islamic and Jewish traditions or Islamic and Roman law. He saw such intersections either as evidence that Islamic law had accepted the local practices of people who came under its rule, or as examples of how legal cultures approach questions of society, governance, and authority in analogous fashion. I contend that 'Annāra's proposal should be read as a censure of the legal elite's disregard for local traditions in favor of wholesale adoption of European codes.

Future research should explore the understudied and suppressed arguments of the movements opposing the adoption of civil law in Egypt. In 1948, a coalition of fourteen leaders of Islamic and judicial organizations ${ }^{122}$ sent a letter to King Fārūq I (d. 1965) seeking his immediate intervention to revisit the government efforts to introduce a revised comprehensive civil law in Egypt. The central concern for the signatories on this letter was the sidelining of Islamic law in favor of European codes. More importantly, the letter called for the adoption of Islamic law as the basis of any new civil code in Egypt. This appeal focused mainly on the sources of the proposed law rather than the mode of legal ordering of the justice system. ${ }^{123}$ Furthermore, these critical accounts in the primary sources connect these persistent codification efforts to the Montreux Convention regarding the abolition of the capitulations in Egypt (concluded on May 8, 1937). ${ }^{124}$

\footnotetext{
${ }^{118}$ This Eurocentric narrative appears prominently in the dedicated work on the same subject by 'Azīz Khānjī. 'Azīz Khānjī, Al-Tashrī' wa-l-qadāa' qabl inshā' al-mahākim al-ahliyya [Legislation and judiciary before the rise of National Courts] (Cairo: al-Mațba'a al-'Așriyya, n.d.)

${ }^{119}$ Al-Sanhūrī, "Min Majallat al-Ahkām al-'Adliyya," 280.

${ }^{120}$ Al-Sanhūrī, 278.

${ }^{121}$ Muhammad Sulaymān, Bỉayy Shar' Nuhkam? al-dawa ilā itikhādh sharī'at al-bilād asāsan lil-taqnīn fihā [By which laws should we be governed? A call to adopt Islamic law as a basis for codification] (Cairo: al-Mațba'a al-Amiriyya, 1936).

${ }^{122}$ These were Muhammad al-Shirbīnī, head of al-Azhar Scholars' Front; Hasan al-Bannā, head of the Muslim Brortherhood; Amīn Khațțāb, head of the Islamic Collective; Judge Muhammad șādiq al-Mahdī, head of the Egypt-Europe Association; Muhammad al-Mahdī al-Ta'ayūshī, head of Sudanese-Egyptian Union; Muhammad Wașfi, head of Upholders of Pilgrimage; Ahmad Ahmad 'Alī, head of the Islamic Education Association; Bayūmī Raḍwān, head of the Union of Mosque Scholars; 'Abd Allāh 'Afîfī, head of Islamic Association of the Brothers of Truth; Husayn Muhammad Yūsuf, head of the Youth Association of the Prophet Muhammad; al-Sayyid Muhammad al-Najjār, head of the Pilgrimage Promotion Association; General Mazūq Yūnus, a member of the committee organized to critique the civil law legislation; General 'Abd al-Wāhid Subul, secretary general for the union; and Hamūda Ghurāba, secretary for the project and a member of the committee.

123 "Ilā Maqām Ḥadrat Șāḥib al-Jalala al-Malik al-Mafdī (Fārūq al-Awwal)" [A letter to His Majesty the King of Egypt, Farūk I], in Naqd li-Mashrū' al-Qānūn al-Madanī al-Manzūur bi-Majlis al-Shuyūkh [A critique of the civil law bill before the parliament] (Cairo: Dār al-Ṭibā'ah wa al-Nashr al-Islāmiyya, 1948), A-B.

${ }^{124}$ A celebratory event was held on October 15, 1937, to commemorate the start of the transition period. King Farūq I, all foreign and Egyptian judges in the Mixed Courts, and official representatives from foreign governments attended the event. Naqd li-Mashrū' al-Qānūn al-Madani al-Manz̄ūr bi-Majlis al-Shuyūkh, 10.
} 
A key prerequisite by participating foreign powers ${ }^{125}$ for the abolition of the capitulations was that the Egyptian code (al-tashrī al-miși) must be on par with modern established codes. ${ }^{126}$ This agreement secured a twelve-year transition period in which all foreigners in Egypt would be subject to Egyptian law by October 14, 1949. In short, careful attention to the arguments and actors involved in these debates give us a wider context for the history of codification in Egypt. The contestation of the utility of codification is not simply a technical question, but also an articulation of certain political and legal positions, as al-Sanhūrī consistently maintained.

\section{Conclusion}

The contestation of the relationship between din and dawla is one of the key cultural rehearsals in modern Muslim political thought-especially after the abolishment of the Ottoman caliphate in 1924. Al-Sanhūrī's theorization of the relationship between din and dawla was an attempt to bring about a sense of continuity between Muslim political thought and the emerging nation state apparatus in the Muslim world. The delineation of the domains of din and dawla in Egyptian legal history was possible through articulation with existing Islamic jurisprudential distinction between the domains of 'ibādāt and mu'āmalāt. This depiction of the relationship between religion and state enabled al-Sanhūrī to promote and legitimize a political and social order that transforms the relationship between state power, religion, and emerging institutions. At the same time, the nature of this transformation invested new authority within the state to manage and decide on a wide range of issues that were deemed outside of the domain of din. The result is a political order founded on a distinction between din and dawla that reorganizes institutional structures of governance and grants the political sovereign ultimate power over the religious domain. Al-Sanhūrī's key contribution to this issue is not only that he deployed the distinction between din and dawla to theorize a potential rapprochement between the postcolonial state and Muslim political thought, but also how he constructed this discourse.

Al-Sanhūrī rendered the term dīn into the domain of ethics and ritual worship, preventing any connotation of state authority over dìn. However, for al-Sanhūrī, dìn maintained certain normative power in society. Thus, the contestations regarding the realm of $\operatorname{din}$ in the writing of modern Muslim intellectuals demonstrate the different orientations that underpin the politics of Islamic law in a given society. Al-Sanhūrī realized that the modern nation state is not a neutral entity and needed to be based on philosophical, social, and political traditions of Muslim thought. In this context, for al-Sanhūrī, the state may enjoy certain authority to decide on religious questions that may affect public policy. I concur with the existing scholarship that al-Sanhürī's engagement with Islamic law in his theorization of a postcolonial Egyptian state should be understood as a manifestation of his nationalist commitments. Because of these nationalist sentiments, the significance of Islamic law, for al-Sanhūrī, lies in the fact that it has been the governing law in Egypt for centuries, with profound social and cultural impact.

Al-Sanhūrī claimed three spheres of continuity in his codification project of the Egyptian civil law: (1) continuity of the postcolonial Egyptian state with Muslim political thought through institutional and constitutional readjustments; (2) continuity of the old civil lawbased primarily on French code-with the new civil law, which is a hybrid of Islamic, European, and French code; and (3) continuity of the new Muslim personal status law with the jurisprudential norms of the Islamic legal schools. One way to situate

\footnotetext{
${ }^{125}$ The United States, United Kingdom, France, Belgium, Greece, Italy, Norway, Denmark, Portugal, Spain, South Africa, Ireland, and Sweden. Wathā'iq Mu'tamar Ilghā' al-Imtiyāzāt [The documents of the conference on capitulations] (Cairo: al-Mațba'a al-Amīinyya, 1937).

${ }^{126}$ Ḥamūda Ghurāba, "Taqdīm" [Introduction] to Naqd li-Mashrūc al-Qānūn al-Madanī al-Manz̄ūr bi-Majlis al-Shuyūkh, $2-4$, at 3 .
} 
al-Sanhūrī's claims of continuity is to understand their production as part of his continuous repositioning within the emerging Egyptian political and legal order.

The critics of the Egyptian Civil Code focused mainly on three arguments. First, they maintained that the persistent European-modeled codification efforts in the late 1940s were externally imposed-they were among the prerequisites of the Montreux Convention regarding the abolition of the capitulations in Egypt. Second, they argued that the introduction of a new comprehensive code must correspond to local customs and indigenous traditions. Thus, the overriding concern was the sources of the proposed law rather than its mode of legal ordering. And third, they explained that the proposed civil law in Egypt was necessarily a legal transplant rather than an organic process of lawmaking. They asserted that profound legal changes, like the proposed project, can only be rationalized in the aftermath of radical political and military transformation, not simply as a piece of legislation during peace time.

The adoption of codification as a universal legal technique-not a concomitant of European legal modernity-enabled al-Sanhūrī to maintain that the key bureaucratic and structural changes in mid-twentieth-century Egypt were necessarily inspired by local tradition ('urf) and Islamic law. They were dubbed essential measures to counter colonial powers and to gain sovereignty over lawmaking. In short, the single most important action by the legal elite in Egypt was the rationalization of the civil code as a legitimate and necessary measure for modernity. The political adoption of the French civil law allowed it to gain hegemonic status and normativity over all local legal traditions.

Acknowledgments. Earlier versions of this article were presented at the workshop "Courts, Religion, and Politics," organized by Tamir Moustafa and Jeffrey Sachs at Simon Fraser University in November 2016, and at the conference "Uses of the Past in Islamic Law," organized by Robert Gleave and Omar Anchassi at the University of Exeter in September 2018. I thank Ahmad Atif Ahmad, Ovamir Anjum, Asli Bali, Guy Burak, Dale Correa, Mohammad Fadel, Omar Farahat, Scott Lucas, Lena Salaymeh, Ari Schriber, and Sohaira Siddiqui for their engagement and comments. All mistakes remain mine.

Cite this article: Ayoub, Samy A. "A Theory of a State? How Civil Law Ended Legal Pluralism in Modern Egypt." Journal of Law and Religion 37, no. 1 (2022): 133-152. https://doi.org/10.1017/jlr.2021.79. 